Pakistan Journal of Humanities and Social Sciences

October - December 2018, Volume 6, No. 4, Pages 561 - 581

\title{
Investigating Customer Satisfaction of Airline Passengers in Aviation Sector of Pakistan
}

\author{
Muhammad Salman Azhar ${ }^{1}$, Ismail Bin Lebai Othman ${ }^{2}$, Norzieiriani bt. Ahmad ${ }^{3}$ \\ ${ }^{1} \mathrm{PhD}$ Scholar, School of Business Management, Universiti Utara Malaysia, Malaysia \\ ${ }^{2}$ Associate Professor, School of Business Management, Universiti Utara Malaysia, Malaysia \\ ${ }^{3}$ Senior Lecturer, School of Business Management, Universiti Utara Malaysia, Malaysia \\ Email: msalmanazhar@ hotmail.com
}

\begin{abstract}
This study aims to measure customer satisfaction by exploring service quality, trust and physical environment as drivers of customer satisfaction in airline industry of Pakistan. The study used a cross-sectional research design. The data collection was done by survey research method through a structured, adopted, modified and self-administered questionnaire. There were 576 questionnaires that were distributed to passengers of three airlines namely; Pakistan International Airline (PIA), Shaheen International Airline (SAI) and Air Blue (ABQ), in five airports of Pakistan. The hypothesis were tested simultaneously on 446 passengers out of 576 questionnaire that were distributed getting a response rate of $71 \%$. The data was analyzed using SPSS (version 21.0) and PLS-SEM (using Smart PLS version 3.2.8) at the 0.05 critical level. The study findings were in line with previous research and expectation disconfirmation theory (EDT) of customer satisfaction. The findings have shown significant association among variables that were examined in the study. Despite the significant association among trust, physical environment and service quality, this study is an addition in the theoretical knowledge of airline industry of Pakistan. Additionally, the study explores influence of trust, physical environment and service quality and their association to how the passengers perceive the service quality, physical environment and their level of trust on service providers whether the passengers are satisfied or not from the international airlines of Pakistan. Also, this study deliver understandings for future research in service marketing area and help travel agencies to employ the implementation of role of service quality, customer trust and physical environment as main drivers of customer satisfaction.
\end{abstract}

Keywords: Customer Satisfaction, Service Quality, Trust, Physical Environment, Expectation Disconfirmation Theory (EDT) 


\section{Introduction}

There had been a significant impact of 2007-2008 economic crisis on world economy which affected entire airline industry of the world, by making it very competitive. Therefore, numerous airlines closed down their set-ups while some of them merged their operations with others for their survival and to compete productively. In previous 25 years, there had been a rapid growth in aviation industry. For many industries aviation industry is a center of globalization it delivers challenges and opportunities for business entities in the industry (Hanlon, 2000). The growth in aviation industry is due to the reason that, it supports trade of the whole world as well as international investment and tourism activities (Hussain, 2016).

In today's competitive environment passenger satisfaction is the key strength for the airline companies, in the case if passenger does not feel satisfied with services provided by airlines, they will reassess their decision of buying for future flights and will possibly alter their decision towards another airline (Archana \& Subha, 2012). The airline services are declining their market share since the deregulation due to the emergence of numerous airlines( Hunter, 2006), and due to the growth in the airline industry customers are not satisfied from the service provided by airlines as compared to the services that were offered previously (Thomas, 2001). So, the airlines extremely compete among themselves in order to obtain passengers' satisfaction (Pitchayadejanant \& Nakpathom, 2016).

Pakistan International Airline (PIA) has been the only Pakistan's airline since 1955 when it has been established (Ali et al., 2015). The Pakistan Civil Aviation Authority (PCAA) was came in to being in 1982, as a controlling body in governing and aligning the activities of civil aviation in the country (Deen \& Arshad, 2007). Pakistan international airline industry is facing a number of issues and challenges; first there is a lack of related personnel and trained staff, the air fares are very high, more and more competitors are entering the industry, the morale of workers is low, a lot to do in order to build its corporate image, the condition of aircrafts is very poor, the flights are cancelled in last minutes and there is a lack of modern technology (Zaheer et al., 2013). Moreover, the international passengers of Pakistan international airlines showed a lack of confidence on it (Deen \& Arshad, 2007; Qasim, 2015; Ali \& Dey, 2011; Nawaz et al., 2012; Khan et al., 2011).

The airline industry of Pakistan is currently facing challenges on both edges inside and outside, it is under progress as it possess a weak infrastructure. Currently, in Pakistan many airlines are operating among them some of them cares about customer satisfaction while some of them ignores it totally, in spite of the fact that in future this will create various 
problems as well as the business experiences loss. All-round the world, airlines are offering superior services to their customers, but in the case of Pakistan the position is contradictory (Zakir et al., 2016).

In Pakistan, there are three major domestic players of airline industry which operates internationally namely: Shaheen Air International Limited (SAI), Pakistan International Airlines (PIA), and Air Blue Limited (ABQ) (JCR VIS sector update, 2016). For many years after its formation PIA remained the only operator, then rapidly private airlines like Shaheen Air, Air Blue and Askari Airline arrived as a competitor of national flag carrier. PIA has captured $71.40 \%$ market share of the industry that is maximum as compared to others, Air Blue has $8.70 \%$ share in the aviation industry of Pakistan (Zaheer et al., 2013).

Numerous drivers of customer satisfaction have been studied in the past that linked customer satisfaction with employee performance (Ambroz \& Praprotnik, 2008), customer value (Hu et al., 2009; Alireza et al., 2011), innovativeness of service (Ambroz \& Praprotnik, 2008), service quality (Hu, Kandampully, \& Juwaheer, 2009) and product reliability (Ganguli, 2008). Similarly, Most of prior studies on airline services have studied service quality in order to describe passenger evaluations of services and customer satisfaction (Archana \& Subha 2012). Though investigating influence of trust, physical environment and service quality as drivers of customer satisfaction in the airline industry will be of great value for airline managers.

Likewise, the drivers of customer satisfaction comprises of physical environment (Azzam, 2012; Lee \& Jeong, 2012; Ali et al., 2013; Ruiz et al., 2012), trust (Krishnamoorthy, Aishwaryadevi \& Bharathi, 2016) are overlooked in prior researches in order to measure customer satisfaction particularly in aviation industry. Hence, the study in hand will investigate the customer satisfaction through service quality, trust and physical environment in order to investigate the reason behind passengers' lack of confidence in airline industry of Pakistan. Moreover, the study attempts to bridge the gaps by examining service quality, trust and physical environment which leads to customer satisfaction in the airline industry of Pakistan.

\section{Theoretical Framework and Research Model}

Expectancy disconfirmation theory (EDT), is among the most well-known theories in the field of marketing that has gained extensive recognition in research that seeks to explain customer satisfaction and repurchase intention of customers (Yen \& Lu, 2008). The EDT was developed by Oliver (1980) and postulated that the post-purchase satisfaction of customer is 
mutually determined by expectancy disconfirmation and pre-purchase expectation. The EDT measures customer's satisfaction from discrepancy among the expectation and experience of customers in perceived products or services (Spreng \& Jr, 2003).

The EDT is among the prevailing theories of customer satisfaction which states that satisfaction level of customers is associated with direction of the disconfirmation experience and size, which follows as an outcome of matching the performance of service against expectations. The customer satisfaction is mainly the consequence of uninterrupted experiences regarding the products or services which happens by comparison of perceptions in contrast to expectations (Mattila \& O’Neill, 2003).

The variation among the desire or initial expectation and performance or perceived experience is known as desire or disconfirmation of expectation (Bhattacherjee \& Premkumar, 2004). The disconfirmation of expectation can be either positive or negative. In the case if the perceived performance of the customer about the quality of a product or service is greater than the expectation of the customer this will lead to the positive disconfirmation. Whereas, in the same way if perceived performance of customer is inferior than what is expected about quality of product or service which lead to negative disconfirmation (Elkhani $\&$ Bakri, 2012). Customer satisfaction and future purchase decisions are achieved as a result of positive disconfirmation. However, the negative disconfirmation results in searching for another product to satisfy customer needs (Mohajerani, 2013).

The theory of disconfirmation not only postulates the effect of disconfirmation of expectations on the level of customer satisfaction whereas it also suggests an influence of expectations and perceived performance on customer satisfaction, the prior expectations of customers may affect them on the way to a particular reaction, for that reason they measure the recovery of service conforming their level of satisfaction to their level of expectations for avoiding dissonance that would rise in the case if these levels were diverse (Szymanski \& Henard, 2001).

The current research study is based on the expectation disconfirmation theory (EDT). Rendering to the current theory, the level of customer satisfaction is determined by the inconsistency among cognitive standards i.e. expectation and desires and perceived performance (Liu \& Khalifa, 2003). Moreover, EDT acknowledged that customer satisfaction is principally illustrated by gap that occurs among desires, expectations and perceived performance which is known to be a favorable method for explaining customer satisfaction. 
Pakistan Journal of Humanities and Social Sciences, 6(4), 2018

This theory proposes that level of satisfaction is influenced by direction (positive or negative), intensity (or size) and gap (disconfirmation) among perceived performance and expectations.

\section{A. Customer Satisfaction}

The word Satisfaction has been a derivative of the word "satis" from the Latin language which means "enough" and "facere" which means to make or to do. Therefore, the products and services that are satisfying have the capability to deliver that is required for being "enough." There are two associated words with satisfaction the one is satiation that roughly means enough up to the point of surplus, while the other one is satiety that means an overabundance or a plentiful of enough, as it is necessarily undesirable to have too much enough of something. So ultimately these terms demonstrates that satisfaction indicates a filling or fulfillment (Masroujeh, 2009).

Moreover, the phenomenon of customer satisfaction is defined as a judgment that is based on a particular service encounter (Huang, 2009). It is defined as the total or complete assessment about the service or a product by the time and as an outcome of purchase and usage experience of the customer (Srivastava, 2015). Customer satisfaction is regarded as a belief of business that leads to the value creation for customers, forestalling and handling their expectations, indicating their capability and obligation to fulfill customer needs (Dominici \& Guzzo, 2010). Customer satisfaction is related to overall evaluation of product or service by customer after the purchase (Choi et al., 2013). It is stated as the evaluation of the post-usage of a product or service by end user in order to deliver joy and fulfilment that is expected by customer (Khan \& Khan, 2014).

Additionally, some researchers indicated that customer satisfaction helps in improving and retaining the long-term customer's relationship among companies. Customer satisfaction is related to the feeling of disappointment or happiness a customer experiences when he or she assesses the perceived effects of certain products as compared to customer expectations about that product effects (Juan \& Yan, 2007). According to customer's perspective, the customer satisfaction can also be seen regarding their needs, wants and expectations all over the life cycle of the product or service have been met or exceeded, delaying unwaveringness and ensuring repurchase (Usta et al., 2014).

Moreover, customer satisfaction can be achieved by recognizing and anticipating customer needs and the firm must have ability to satisfy them. The companies make larger profits which have an ability to promptly understand and satisfy needs of customers, than those which are unsuccessful to understand and satisfy them (Barsky \& Nash, 2003). The 
phenomenon of satisfaction is thoroughly associated to the expectations and experience of consumers. For any organization to accomplish its objective customer satisfaction is the termed as its basis, or it can be said as the degree of customer satisfaction reveals the achievement rate of objectives of organization (Odunlami \& Matthew, 2015).

\section{B. Physical Environment}

Physical environment includes the substantial atmosphere in which the service products are delivered (Nguyen \& Leblanc, 2002). The study of Ruiz, Castro, \& Diaz (2012) have showed that physical environment is an essential element for the customer satisfaction. The prior research proposes that there is an uninterrupted connection among physical environment and customer satisfaction (Chebat \& Michon, 2003; Ryu, \& Han, 2010). Similarly, Chang (2000) proposed that physical environment is an indicator of customer satisfaction, thus signifying that customer satisfaction has a direct and positive association with features of positive behavior of customers (Ryu \& Han, 2010).

Several researches have focused on how the perception of customer about physical environment effect their satisfaction levels in service settings where they pass a substantial time period (Han \& Ryu, 2009; Slatten Krogh \& Connolley, 2011; Ryu et al., 2012). The progressive views about physical environment can lead to customer satisfaction with the service providers that is followed by likelihood to endorse the services provider to others (Ryu et al., 2012).

Moreover, past studies supported that physical environment has significant influence on customer satisfaction Nam et al., (2011), Ryu et al.,(2012), Gagic et al., (2013). Various scholars discovered that physical environment is an essential indication that customer is incline to use for the assessment of the value he/she receives from a service offering (Ali et al., 2013; Yang \& Chen, 2010). Therefore, it leads to the following hypothesis:

$\mathbf{H}_{1}$ : Physical Environment has a significant relationship with Customer Satisfaction.

\section{Service Quality}

Service quality a whole imprint of firm's effectiveness its services on consumers (Park et al., 2004) or it is a sequence of services in which service delivery is distributed into a chain of procedures (Chen \& Chang, 2005). It is also defined as an extent to which a service meets or exceeds the needs and expectations of customers (Gursoy et al., 2005; Namukasa, 2013).

In order to gain a superior customer satisfaction level, numerous researches illustrates that a greater service quality level should be provided by the service provider 
(Baker, 2013). Previous scholars have specified that there is a progressive relationship between customer satisfaction and service quality (Kuo et al., 2009; Haghighi et al., 2012; Gonzalez et al., 2007 and Zhao et al., 2012). A number of studies illustrate that service quality impacts customer satisfaction, amongst other studies are conducted by Shirsavar et al., (2012), Lien et al., (2011), Taleghani et al., (2011), Marinković et al., (2012), Fang et al. (2011), Karim, (2012), Parasuraman et al., (1988), Brady \& Cronin, (2001), Liao, (2012), Ou et al., (2011), Huang, (2008) as well as Terblanche \& Boshoff (2001), Hume \& Mort (2010). Moreover, service quality is either an antecedent on customer satisfaction or has an effect on customer satisfaction (Kuo, Wu, \& Deng, 2009; Koivumäki, Ristola, \& Kesti 2008; Yee, Yeung, \& Cheng, 2008). Hence, this leads to following hypotheis:

$\mathbf{H}_{2}$ : Service quality has a significant relationship with Customer Satisfaction.

\section{Trust}

Trust is defined as a party's willingness based on expectation to be exposed to another party's actions that the trustee will accomplish a specific action that is essential to trustor, regardless of the capability to control or monitor that other party (Zhu \& Chen, 2012). Trust is known to be as the essential factor that facilitates people in order to construct relationship in the uncertainty. Similarly, it is vigorous factor for building strong relationships with customers and obtaining market share which must be accomplished earlier to customer satisfaction (Kutol \& Juma, 2016).

Moreover, trust can be observed as an intention of trust and a belief of trust. The trusting intention is the willingness or trustor's intention to depend on the trustee while trusting belief discusses user's perceptions of service provider's characteristics, comprising of integrity, ability, and benevolence (Deng, Lu, Wei, \& Zhang, 2010). When a service provider is being trusted by the customer than an increase in satisfaction level and loyalty towards that service provider is expected (Kassim \& Abdullah, 2008).

Scholars have found that in long-run, the trust will affect customer satisfaction (Kim, Ferrin, \& Rao, 2009). Prior literature reveals that interdependencies exist between satisfaction and trust (Kennedy, Ferrell, \& LeClair, 2001; Thomas, Cunningham, \& Williams, 2002). Trust is based on past satisfaction experiences (Naskrent \& Siebelt, 2011). On the basis of relationship among satisfaction and trust, the customer trust has been viewed from a comprehensive view as the company's overall impression.

Thus, as customer satisfaction with the firm increases, there would be an increase in customer trust towards the company (Roman, 2003). The increase in customer satisfaction 
will assist in building customer trust (Teimouri et al., 2012). Numerous studies have shown a relationship among trust and satisfaction (Platonova et al., 2008; Kim, Ferrin, \& Rao, 2009). This leads to following hypothesis:

$\mathbf{H}_{3}$ : Trust has a significant relationship with Customer Satisfaction.

\section{Research Methodology}

The data collection was done from three airline of Pakistan namely; Shaheen International Airlines (SAI), Pakistan International Airlines (PIA) and Air Blue (ABQ). For the sample size determination of study, the researcher used past year passengers statistics (2017-18) of civil aviation authority to determine total number of people that have journeyed through these three airlines. Additionally, a cross-sectional survey through the help of structured questionnaire was administered to passengers at five (Peshawar, Quetta, Karachi, Islamabad and Lahore) international airports of Pakistan

A 5-point Likert scale was used to measure the items of questionnaire. Furthermore, questionnaire was divided in to three main sections: Section A, that included the demographic variables such as gender, age group, nationality, marital status, highest level of education, occupation, financial earnings (monthly) and Section B, that comprised of sixteen (14) items to measure; service quality, physical environment and trust. There were 5 items that measured customer satisfaction with the three airline services providers.

The fiscal year (2017-18) statistics of passengers that had travelled through Shaheen International Airlines, Pakistan International Airlines and Air Blue were 6,451,970 passengers were employed in the study as the total population (PCAA, 2018). Moreover, the study used a sample size was 384 respondents (Krejcie \& Morgan, 1970). Anticipating the low response rate, the researcher distributed more questionnaires as suggested by (Miller \& Salikind, 2002), using the over sampling method by increasing sample size by 40 to $50 \%$ to address the issue of low response rate and unusable responses. Therefore, study increased the sample size 384 by $50 \%$ so, the total questionnaire distributed were 576 .

The study employed PLS structural equation modeling (SEM) using the software application Smart PLS (Ringle, Wende, \& Will, 2010) path modelling (Version 3.2.8) in order to estimate research model. Moreover, the study used a two-step procedure of PLS to evaluate and report the PLS-SEM path results according to the recommendations of Henseler, Ringle \& Sinkovics, (2009). The two steps include: (1) The assessment of Measurement (Outer) Model and (2) The Assessment of Structural (Inner) Model (Hair et al., 2016). 


\section{Results}

The demographic features that were examined in the study were gender, age, marital status, highest educational level, and occupation, financial earnings which were measured on nominal and ordinal scale are shown in the Table 1. In demographic analysis the distribution of respondent's preliminary based on the gender, which showed that $(58.3 \%)$ were male while $(41.7 \%)$ were female. The age of respondents illustrate that majority of respondents were 2030 years old $(29.8 \%)$, about (25.6\%) fall within the age of 31-40 years and remaining (18.8\%) were falling in the age of 41-50 years. With respect to marital status it was observed that most of the respondents were married (69.1\%) and about $30.9 \%$ were single.

Table 1: Sample Profile of Respondents

\begin{tabular}{|c|c|c|}
\hline Demographic variables & Frequency & Percentage (\%) \\
\hline \multicolumn{3}{|l|}{ Gender } \\
\hline Male & 260 & 58.3 \\
\hline Female & 186 & 41.7 \\
\hline \multicolumn{3}{|l|}{ Age } \\
\hline Below 20 & 41 & 9.2 \\
\hline $20-30$ & 133 & 29.8 \\
\hline $31-40$ & 114 & 25.6 \\
\hline $41-50$ & 84 & 18.8 \\
\hline Above 50 & 74 & 16.6 \\
\hline \multicolumn{3}{|l|}{ Marital Status } \\
\hline Married & 308 & 69.1 \\
\hline Single & 138 & 30.9 \\
\hline \multicolumn{3}{|l|}{ Nationality } \\
\hline Pakistani & 331 & 74.2 \\
\hline Foreigner & 115 & 25.8 \\
\hline \multicolumn{3}{|l|}{ Highest Educational level } \\
\hline Diploma & 38 & 8.5 \\
\hline Bachelors & 150 & 33.6 \\
\hline Masters & 178 & 39.9 \\
\hline $\mathrm{PhD}$ & 67 & 15.0 \\
\hline Others & 13 & 2.9 \\
\hline \multicolumn{3}{|l|}{ Occupation } \\
\hline Employed & 225 & 50.4 \\
\hline Self-employed & 89 & 20 \\
\hline Job seeker & 25 & 5.6 \\
\hline Student & 93 & 20.9 \\
\hline Others & 14 & 3.1 \\
\hline \multicolumn{3}{|l|}{ Financial Earnings } \\
\hline Below 49,999 & 113 & 25.3 \\
\hline $50,000-99,999$ & 186 & 41.7 \\
\hline 100000 - 199999 & 92 & 20.6 \\
\hline 200000 and above & 55 & 12.3 \\
\hline
\end{tabular}


Furthermore, it was also observed that about (39.9\%) respondents were holder of master's degree, and (33.6\%) respondents had bachelor's degree, about (15\%) respondents were $\mathrm{PhD}$ degree holder and remaining (8.5\%) were holder of diploma or equivalent degree and $(2.9 \%)$ fall in the category of others. The occupational background of the respondents illustrate that about (50.4\%) of the respondents were employed, about (20.9\%) were students, (5.6\%) were job seekers and (3.1\%) fall in the category of others.

With respect to financial earnings it was observed that most of respondents (41.7\%) fall in the category of 50,000 - 99,999, while (25.3\%) earn below 49,999, (20.6\%) had financial earnings of 100000- 199999 and (12.3\%) had financial earnings of 200000 and above as described in the table 1 .

\section{A. Measurement Model}

The measurement model is evaluated according to the criteria of outer loading of individual items 0.5 or above and the value of average variance extracted (AVE) should be above than 0.5 as well (Vinzi et al., 2010). All variables of the study were adopted from the prior studies therefore, researcher only performed Confirmatory Factor Analysis (CFA) to validate the measurement model (outer model) by examining the relationship between items/indicators and their respective underlying construct, using PLS-SEM (Henseler, Hubona \& Ray, 2017).Moreover, the outer loading of all the items are more than 0.5 (Hair et al., 2013; Hair et al., 2016).

All the CR coefficient of each latent variables ranged from 0.852 to 0.99 and each value exceeds the minimum acceptable level of 0.70 which suggests that adequate internal consistency reliability of measure was used in this study. Moreover, the Cronbach's alpha value were also calculated in this study to validate the internal consistency of the constructs as shown in table 2.

All AVE values of study exhibited higher loadings that were greater than 0.50 which showed an adequate convergent validity. Moreover, discriminant validity using AVE values was done by equating correlations among the latent variables with square roots of AVE (Fornell \& Larcker, 1981). In order to observe discriminant validity, the study undertaken the model's external consistency, to compare the value of AVE of all latent variables that were shown in table 2 . 
Table 2: Results of Measurement Model

\begin{tabular}{|c|c|c|c|c|c|}
\hline Constructs & Items & Loadings & Cronbach's alpha & $\mathbf{C R}$ & AVE \\
\hline \multirow[t]{5}{*}{ Physical Environment (PE) } & & & 0.872 & 0.906 & 0.661 \\
\hline & PE1 & 0.837 & & & \\
\hline & PE2 & 0.884 & & & \\
\hline & PE3 & 0.891 & & & \\
\hline & PE4 & 0.803 & & & \\
\hline \multirow[t]{7}{*}{ Service Quality (SQ) } & & & 0.870 & 0.899 & 0.563 \\
\hline & SQ1 & 0.809 & & & \\
\hline & SQ2 & 0.817 & & & \\
\hline & SQ3 & 0.755 & & & \\
\hline & SQ4 & 0.768 & & & \\
\hline & SQ5 & 0.713 & & & \\
\hline & SQ6 & 0.796 & & & \\
\hline \multirow[t]{5}{*}{ Trust (TR) } & & & 0.771 & 0.852 & 0.589 \\
\hline & TR1 & 0.763 & & & \\
\hline & TR2 & 0.784 & & & \\
\hline & TR3 & 0.745 & & & \\
\hline & TR4 & 0.779 & & & \\
\hline \multirow[t]{6}{*}{ Customer Satisfaction (CS) } & & & 0.874 & 0.909 & 0.668 \\
\hline & CS1 & 0.793 & & & \\
\hline & $\mathrm{CS} 2$ & 0.858 & & & \\
\hline & CS3 & 0.856 & & & \\
\hline & CS4 & 0.854 & & & \\
\hline & $\mathrm{CS}$ & $5 \quad 0.716$ & & & \\
\hline
\end{tabular}

Note: CS - Customer Satisfaction; PE - Physical Environment; SQ - Service Quality; TR - Trust

Table 2.1: Latent Variable Correlations and Square Roots of AVE (Fornell - Larcker Criterion)

\begin{tabular}{|c|c|c|c|c|}
\hline & CS & PE & SQ & TR \\
\hline \hline CS & $\mathbf{0 . 8 1 7}$ & - & - & - \\
\hline PE & 0.345 & $\mathbf{0 . 8 1 3}$ & - & - \\
\hline SQ & 0.464 & 0.210 & $\mathbf{0 . 7 5 0}$ & - \\
\hline TR & 0.485 & 0.227 & 0.288 & $\mathbf{0 . 7 6 8}$ \\
\hline
\end{tabular}

Note: Entries shown in boldface represent the square root of the AVE, CS - Customer Satisfaction; PE - Physical Environment; SQ - Service Quality; TR - Trust

Moreover, discriminant validity was checked by equating indicator loadings with other reflective indicators cross loadings (Chin, 1998). According to the rule of thumb, AVE values with score of 0.50 or more is considered for evaluation of discriminant validity (Fornell \& Larcker, 1981). Additionally, a recently developed estimation tool in variancebased SEM to assess the factors correlation is the heterotrait-monotrait ratio of correlations (HTMT) (Henseler, Ringle, \& Sarstedt, 2015; Pittino, Martinez, Chirico, \& Galvan, 2018). The HTMT ratio is vital tool for the evaluation of the model which outclass the old approach for discriminant validity that is Fornell-Larcker criterion. According to the criteria of HTMT 
ratio, the values should be below 0.90 which shows that discriminant validity has been established among reflective constructs (Henseler et al., 2015) as shown in table 3. Therefore, following the HTMT criteria, all variables achieved discriminant validity.

Table 3: Discriminant Validity Matrix, Heterotrait - Monotrait Ratio (HTMT)

\begin{tabular}{|c|c|c|c|c|}
\hline & CS & PE & SQ & TR \\
\hline \hline CS & - & - & - & - \\
\hline PE & 0.371 & - & - & - \\
\hline SQ & 0.525 & 0.239 & - & - \\
\hline TR & 0.569 & 0.273 & 0.349 & - \\
\hline
\end{tabular}

Note: Entries shown in boldface represent the square root of the AVE, CS - Customer Satisfaction; PE - Physical Environment; SQ - Service Quality; TR - Trust

\section{Figure 1: Results of Measurement Model (PLS Algorithm)}

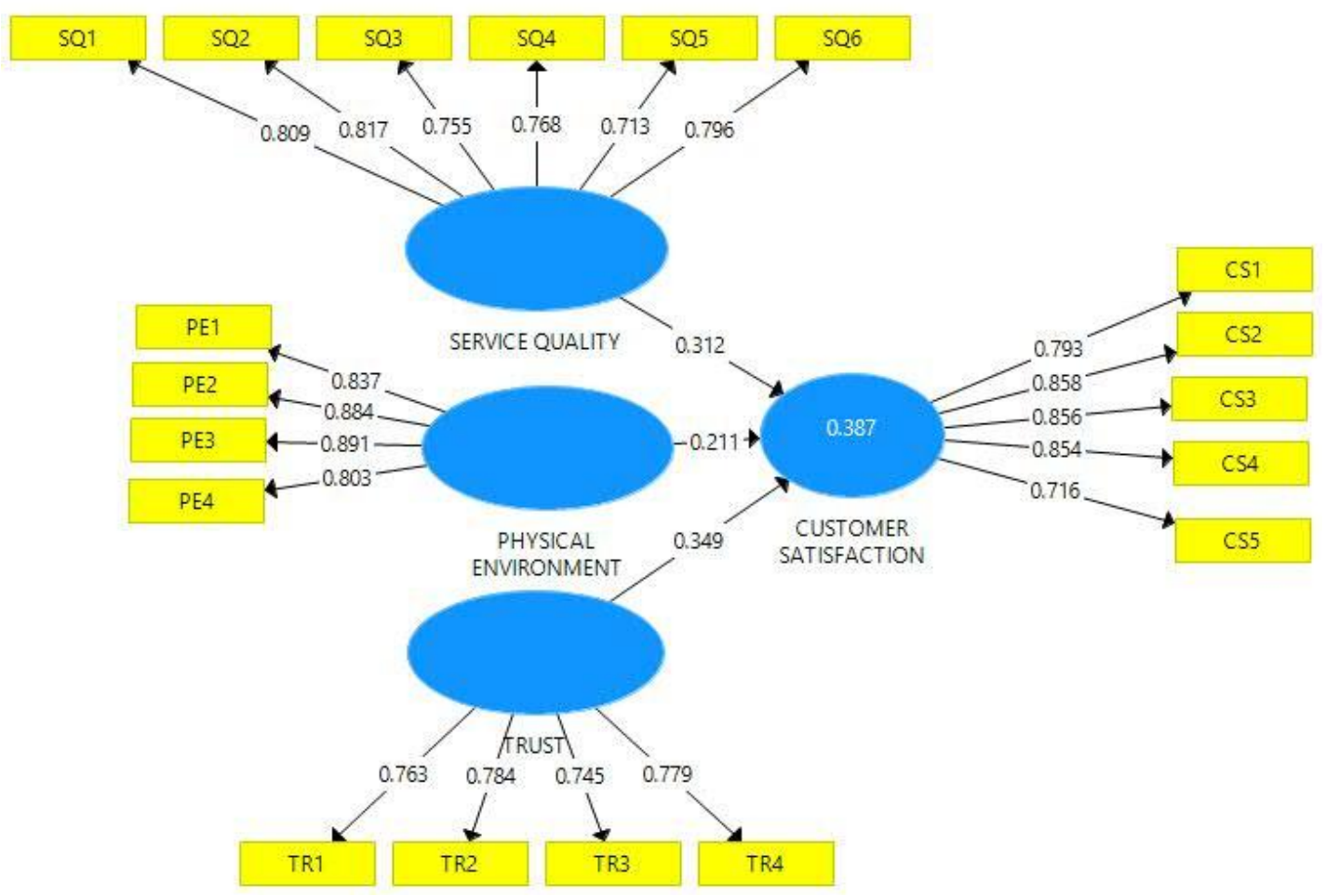

\section{B. Structural Model}

The study applied a standard procedure of bootstrapping with 500 bootstrap samples and 446 data cases examining the path coefficient's significance (Hair, Sarstedt, Hopkins, \& Kuppelwieser, 2014). In this study, $\mathrm{R}^{2}$ of endogenous variable is within the acceptable range as the $\mathrm{R}^{2}$ of customer satisfaction 0.387 . The Table 4 illustrates $R^{2}$ of endogenous latent variables of this study. 
Pakistan Journal of Humanities and Social Sciences, 6(4), 2018

Table 4: R-square of Endogenous Latent Constructs

\begin{tabular}{|lcc|}
\hline Construct & $\boldsymbol{R}$ Square & Result \\
\hline Customer Satisfaction & 0.387 & Substantial \\
\hline
\end{tabular}

Moreover, the findings have shown that all three hypothesized relationships were supported. The results confirmed a significant relationship among physical environment and customer satisfaction was found $(\beta=0.211, t=6.067$, $p$ value $=0.000)$. Hence, Hypothesis 1 is supported. The research results confirmed a significant relationship among service quality and customer satisfaction was found $(\beta=0.312, \mathrm{t}=5.213$, $\mathrm{p}$ value $=0.000)$. Thus, Hypothesis 2 is supported. The research result confirmed a significant association among trust and customer satisfaction was found $(\beta=0.349, \mathrm{t}=7.788$, $\mathrm{p}$ value $=0.000)$. Hence, Hypothesis 3 is supported. The table 5 below, is showing the results of bootstrapping.

\section{Table 5: Results of hypothesis testing relationship with Customer Satisfaction (CS)}

\begin{tabular}{|llcllll|}
\hline Hypotheses & Relationship & Beta & SE & t-value & P-value & Decision \\
\hline H1 & PE $->$ CS & 0.211 & 0.035 & 6.067 & 0.000 & Supported \\
H2 & PQ -> CS & 0.312 & 0.060 & 5.213 & 0.000 & Supported \\
H3 & TR -> CS & 0.349 & 0.045 & 7.788 & 0.000 & Supported \\
\hline
\end{tabular}

Note: CS - Customer Satisfaction; PE - Physical Environment; SQ - Service Quality; TR - Trust

Moreover, the study findings revealed that physical environment, service quality and trust are fundamental drivers of customer satisfaction in the airline industry of Pakistan.

\section{Discussion}

The study aims to test the effect physical environment, service quality, and trust on customer satisfaction in airline industry of Pakistan. The results of study were in line with the researcher expectation and expectation disconfirmation theory (EDT). It was found that there is a significant association among physical environment, trust and service quality with customer satisfaction as indicated in SEM.

The study findings have shown that physical environment is statistically significant to customer satisfaction in airline industry of Pakistan, and therefore, hypothesis (H1) is supported. The findings of study collaborated with prior studies that, physical environment has a significant influence on customer satisfaction (Nam et al., 2011; Ryu et al., 2012; Gagic et al., 2013; Haery \& Badiezadeh, 2014). Various scholars discovered that physical environment is one of the fundamental indications that customer is incline to use for the assessment of the value he/she receives from a service offering (Ali et al., 2013; Yang \& Chan, 2010) 
Similarly, hypothesis (H2), that service quality is associated with customer satisfaction is discovered to be significant and supported. Consistent with the prior study's findings, service quality is either an antecedent on customer satisfaction or has an effect on customer satisfaction (Kuo, Wu, \& Deng, 2009; Koivumäki, Ristola, \& Kesti, 2008; Yee, Yeung, \& Cheng, 2008). For the profitability, sustainable growth and survival of airline, the provision superior quality services is very essential. The airlines achieve competitive advantage by maintaining their service quality that leads to customer satisfaction. The customer satisfaction level of customer provides benefits to organization by building strong relationships among airlines and their passengers (Rizan, 2010; Hussain, 2016). Hence, airlines should constantly upgrade their service quality in long run that will generate greater market share and profit in the future.

Moreover, hypothesis (H3) which illustrates that trust is correlated to customer satisfaction is discovered to be significant and supported. In other words, the study findings are consistent with past studies which reveals that interdependencies exist between satisfaction and trust (Kennedy, Ferrell, \& LeClair, 2001; Thomas, Cunningham, \& Williams, 2002). There is a significant relationship exist among trust and satisfaction (Kim, Ferrin, \& Rao, 2009; Platonova et al., 2008). On the basis of relationship among satisfaction and trust, the customer trust has been viewed from a comprehensive view as the company's overall impression. Thus, as the customer satisfaction with the firm increases, there would be an increase in the customer trust towards the company (Roman, 2003). The increase in customer satisfaction will assist in building the customer trust (Teimouri et al., 2012).

\section{A. Conclusion}

The study examined the association between service quality, physical environment and trust on customer satisfaction in passengers of three international airlines of Pakistan. Furthermore, EDT theory were used as a basis to study the proposed theoretical relationships. All of the three research hypothesis were supported, giving much empirical support to the research model. According to the findings of study, it is determined that directors of the airlines need to build trust, enhance their physical environment and develop strategies to improve service quality and increase satisfaction level of passengers of airlines of Pakistan.

\section{B. Limitations and Future Research}

The above-mentioned discussion of the limitations proposes a host of additional research which may extend the findings of this study, even though the study has provided various hypothesized association among the independent and dependent latent variables. 
Similarly, the study offers and makes recommendations for upcoming research to make the findings of study more robust. Moreover, this study was quantitative, and the researcher relied on questionnaire data only for statistical analysis. Future research may consider using qualitative or mixed mode methods to examine customer satisfaction that may include the use of interviews from the customers for obtaining interpretive and more in-depth information about variables of study.

Additionally, the study used a survey questionnaire research design that involved the use of cross-sectional data at one point in time for testing the hypothesized relationships. For future research the study may consider longitudinal research design for expanding the findings of research. Additionally, this study considered only three international airlines. Future research may examine the domestic airlines in order to make comparison among the domestic travelers and international travelers respectively. Moreover, potential opportunities of forthcoming research would be current model application in other service industries that might include transportation sector (e.g. railways and road transport), education sector, the hospitality or banking sector for testing generalizability of the model. 


\section{References}

Ali, F., Dey, B.L., \& Filieri, R. (2015), An Assessment of Service Quality and Resulting Customer Satisfaction in Pakistan International Airlines. International Journal of Quality \& Reliability Management, 32(5), 486 - 502.

Ambrož, M., \& Praprotnik, M. (2008). Organisational effectiveness and customer satisfaction. Organizacija, 41(5), 161-173.

Archana, R. and Subha, M.V. (2012), A Study on Service Quality and Passenger Satisfaction on Indian Airlines. International Journal of Multidisciplinary Research, 2(2), 50-63.

Azzam, Z. A. M. (2014). The Impact of Customer Relationship Management on Customer Satisfaction in the Banking Industry -A Case of Jordan. European Journal of Business and Management, 6(32), 99-112.

Barsky J., \& Nash L. (2003). Customer satisfaction: Applying concepts to industry- wide measures. The Cornell Hotel and Restaurant Administration Quarterly, 44 (4): 173183.

Bhattacherjee, A., \& Premkumar, G. (2004). Understanding changes in belief and attitude toward information technology usage: A theoretical model and longitudinal test. MIS quarterly, 229-254.

Brady, M. K., Cronin, J. J., \& Brand, R. R. (2002). Performance-only measurement of service quality: a replication and extension. Journal of business research, 55(1), 17-31.

Chang, K. (2000). The impact of perceived physical environments on customers' satisfaction and return intentions. Journal of Professional Services Marketing, 21(2), 75-85.

Chebat, J. C., \& Michon, R. (2003). Impact of ambient odors on mall shoppers' emotions, cognition, and spending: A test of competitive causal theories. Journal of Business Research, 56(7), 529-539.

Chen, F. Y., \& Chang, Y. H. (2005). Examining airline service quality from a process perspective. Journal of Air Transport Management, 11(2), 79-87.

Chin, W. W. (1998). The partial least squares approach to structural equation modeling. Modern methods for business research, 295(2), 295-336.

Choi, E. K., Wilson, A., \& Fowler, D. (2013). Exploring customer experiential components and the conceptual framework of customer experience, customer satisfaction, and actual behavior. Journal of foodservice business research, 16(4), 347-358.

Deen, H. U. D. H. U., \& Arshad, S. (2007). Challenges for the commercial airline industry in Pakistan. Market Forces, 2(4).

Deng, Z., Lu, Y., Wei, K. K., \& Zhang, J. (2010). Understanding customer satisfaction and loyalty: An empirical study of mobile instant messages in China. International journal of information management, 30(4), 289-300.

Dominici, G., \& Guzzo, R. (2010). Customer satisfaction in the hotel industry: A case study from Sicily. International Journal of Marketing Studies, 2(2), 3-12

Elkhani, N., \& Bakri, A. (2012). Review on "expectancy disconfirmation theory"(EDT) Model in B2C E-Commerce. Journal of information systems research and innovation, 2(12), 95-102.

F. Hair Jr, J., Sarstedt, M., Hopkins, L., \& G. Kuppelwieser, V. (2014). Partial least squares structural equation modeling (PLS-SEM) An emerging tool in business research. European Business Review, 26(2), 106-121.

Fang, Y. H., Chiu, C. M., \& Wang, E. T. (2011). Understanding customers' satisfaction and repurchase intentions: An integration of IS success model, trust, and justice. Internet Research, 21(4), 479-503. 
Fornell, C., \& Larcker, D. F. (1981). Evaluating structural equation models with unobservable variables and measurement error. Journal of marketing research, 39-50.

Gagić, S., Tešanović, D., \& Jovičić, A. (2013). The vital components of restaurant quality that affect guest satisfaction. Turizam, 17(4), 166-176.

Ganguli, S. (2008). Drivers of Customer Satisfaction in the Indian Cellular Services Market. ICFAI Journal of Management Research, 7(6), 51-69.

González, M. E. A., Comesaña, L. R., \& Brea, J. A. F. (2007). Assessing tourist behavioral intentions through perceived service quality and customer satisfaction. Journal of business research, 60(2), 153-160.

Gursoy, D., Chen, M-H. \& Kim, H.J. (2005). The US airlines relative positioning based on attributes of service quality. Journal of Tourism Management, 26, 57-67.

Haghighi, M., Dorosti, A., Rahnama, A., \& Hoseinpour, A. (2012). Evaluation of factors affecting customer loyalty in the restaurant industry. African Journal of Business Management, 6(14), 5039.

Hair, J. F., Ringle, C. M., \& Sarstedt, M. (2013). Partial least squares structural equation modeling: Rigorous applications, better results and higher acceptance. Long Range Planning, 46(1-2), 1-12.

Hair Jr, J. F., Hult, G. T. M., Ringle, C., \& Sarstedt, M. (2016). A primer on partial least squares structural equation modeling (PLS-SEM). Sage Publications.

Han, H., \& Ryu, K. (2009). The roles of the physical environment, price perception, and customer satisfaction in determining customer loyalty in the family restaurant industry. Journal of Hospitality and Tourism Research, 33(4), 487-510.

Hanlon,P.(2000).Global Airlines(2nd Edition).Oxford: Butterworth-Heinemann

Henseler, J., Hubona, G., \& Ray, P. A. (2017). Partial least squares path modeling: Updated guidelines. In Partial Least Squares Path Modeling (pp. 19-39). Springer, Cham.

Henseler, J., Ringle, C. M., \& Sinkovics, R. R. (2009). The use of partial least squares path modeling in international marketing. In New challenges to international marketing (pp. 277-319). Emerald Group Publishing Limited.

Henseler, J., Ringle, C. M., \& Sarstedt, M. (2015). A new criterion for assessing discriminant validity in variance-based structural equation modeling. Journal of the academy of marketing science, 43(1), 115-135.

Hu, H., Kandampully, J., \& Juwaheer, T. D. (2009). Relationships and impacts of service quality, perceived value, customer satisfaction, and image: an empirical study. The Service Industries Journal, 29(2), 111-125.

Huang, Y.K. (2009). The effect of airline service quality on passengers' behavioral intentions using SERQUAL scores in Taiwan. Journal of the Eastern Asia Society for Transportation Studies, 8(2), 3-5.

Huang, W. H. (2008). The impact of other-customer failure on service satisfaction. International Journal of Service Industry Management, 19(4), 521-536.

Hume, M., \& Sullivan Mort, G. (2010). The consequence of appraisal emotion, service quality, perceived value and customer satisfaction on repurchase intent in the performing arts. Journal of Services Marketing, 24(2), 170-182.

Hunter, J. A. (2006). A correlational study of how airline customer service and consumer perception of airline customer service affect the air rage phenomenon. Journal of Air Transportation, 11(3), 78.

Hussain, R., Al Nasser, A., Hussain, Y.K., (2015). Service quality and customer satisfaction of a UAE-based airline: an empirical investigation. J. Air Transp. Manag. 42, $167 \mathrm{e} 175$. 
$\begin{array}{llllllll}\text { JCR-VIS SECTOR UPDATE. (2016) retrieved on januaury } 20 & 2017\end{array}$ http://jcrvis.com.pk/docs/Aviation201608.pdf

Juan, L. U., \& Yan, L. U. (2009). Dimensions and influencing factors of customer loyalty in the intermittent service industry. Frontiers of Business Research in China, 3(1), 6378.

Karim, F. (2012). Customer satisfaction and awareness of Islamic banking products and services in Pakistan. Interdisciplinary Journal of contemporary research in Business, 4(4), 384-401.

Kassim, N. M., \& Abdullah, N. A. (2008). Customer loyalty in e-commerce settings: an empirical study. Electronic Markets, 18(3), 275-290.

Kennedy, M. S., Ferrell, L. K., \& LeClair, D. T. (2001). Consumers' trust of salesperson and manufacturer: an empirical study. Journal of Business Research, 51(1), 73-86.

Khan, M., Yaqub, M., Faisal, F. and Khan, M. (2011). Privatization in emerging markets: Pakistan's perspective. Interdisciplinary Journal of Research in Business, 4(1), 101106.

Kim, D. J., Ferrin, D. L., \& Rao, H. R. (2009). Trust and satisfaction, two stepping stones for successful e-commerce relationships: A longitudinal exploration. Information systems research, 20(2), 237-257.

Koivumäki, T., Ristola, A., \& Kesti, M. (2008). The effects of information quality of mobile information services on user satisfaction and service acceptance-empirical evidence from Finland. Behaviour \& Information Technology, 27(5), 375-385.

Krejcie, R. V., \& Morgan, D. W. (1970). Determining sample size for research activities. Educational and psychological measurement, 30(3), 607-610.

Krishnamoorthy, V., Aishwaryadevi, A. S., \& Bharathi, B. (2016). An examination of influence of higher education service quality on students' satisfaction: An Indian perspective. Indira Management Review, 10(2), 95-102.

Kuo, Y. F., Wu, C. M., \& Deng, W. J. (2009). The relationships among service quality, perceived value, customer satisfaction, and post-purchase intention in mobile valueadded services. Computers in human behavior, 25(4), 887-896.

Kutol, W. J., \& Juma, D. (2016). Customer Relationship Management on Customer Satisfaction in Kenyan Multinational Companies: A Case Study of Laborex Kenya. Strategic Journal of Business \& Change Management, 3(4).

Lee, S., \& Jeong, M. (2012). Effects of e-service scape on consumers' flow experiences. Journal of Hospitality and Tourism Technology, 3(1), 47-59.

Liao, K. H. (2012). Service quality, and customer satisfaction: Direct and indirect effects in a B2B customer loyalty framework. Journal of global business management, 8(1), 86.

Lien, C. H., Wen, M. J., \& Wu, C. C. (2011). Investigating the relationships among e-service quality, perceived value, satisfaction, and behavioral intentions in Taiwanese online shopping. Asia Pacific Management Review, 16(3), 211-223.

Liu, V., \& Khalifa, M. (2003). Determinants of satisfaction at different adoption stages of Internet-based services. Journal of the association for information systems, 4(1), 12.

Marinkovic, Veljko; Vladimir Senic, SasaObradovic, andSrdanSapic. 2012. Understanding antecedents of customer satisfaction and word of mouth communication: Evidence from hypermarket chains, African Journal of Business Management, Vol. 6(29), pp. $8515-8524$

Masroujeh, W. F. T. (2009). Critical factors for customer satisfaction and delight in the Palestinian pharmaceutical market (Doctoral dissertation, Islamic University-Gaza). 
Pakistan Journal of Humanities and Social Sciences, 6(4), 2018

Mattila, A. S\& O’Neill, J.W. (2003). Relationships between hotel room pricing, occupancy and guest satisfaction: A longitudinal case of mid-scale hotel in the United States. Journal of Hospitality \& Tourism Research, 27(3), 328-341.

Miller, D. C., \& Salkind, N. J. (2002). Handbook of research design and social measurement. Sage.

Mohajerani, P. (2013). Customer Satisfaction: A Structural Equation Modeling Analysis. Australian Journal of Business and Management Research, 3(3), 1.

Namukasa, J. (2013). The influence of airline service quality on passenger satisfaction and loyalty: The case of Uganda airline industry. TQM Journal, 25(5), 520-532. doi: 10.1108/tqm-11-2012-0092

Nam, J., Ekinci, Y., \& Whyatt, G. (2011). Brand equity, brand loyalty and consumer satisfaction. Annals of Tourism Research, 38(3), 1009-1030.

Naskrent, J., \& Siebelt, P. (2011). The influence of commitment, trust, satisfaction, and involvement on donor retention. Voluntas: International Journal of Voluntary and Nonprofit Organizations, 22(4), 757-778.

Nawaz, N., Manzoor, S., Jahanian, A. \& Mumtaz, R. (2012). Factors underlying the failure of organizations: a focus on Pakistan International Airlines. Journal of Law, Policy and Globalization, 6(1), 1-7.

Nguyen, N., \& Leblanc, G. (2002). Contact personnel, physical environment and the perceived corporate image of intangible services by new clients. International Journal of Service Industry Management, 13(3), 242-262.

Odunlami, B., \& Matthew, O. (2015). Impact of Customer Satisfaction on Customer Loyalty: A Case Study of a Reputable Bank in Oyo, Oyo State, Nigeria. International Journal of Managerial Studies and Research (IJMSR), 3(2), 59-69.

Oliver, R. L. (1980). A cognitive model of the antecedents and consequences of satisfaction decisions. Journal of marketing research, 460-469.

Ou, W. M., Shih, C. M., Chen, C. Y., \& Wang, K. C. (2011). Relationships among customer loyalty programs, service quality, relationship quality and loyalty: An empirical study. Chinese Management Studies, 5(2), 194-206.

Pakistan Civil Aviation Authority. (2018) retrieved on January 112019 http://www.caapakistan.com.pk/upload/AT/stats/2017\%20-\%202018-OPT.pdf

Parasuraman, A., Zeithaml, V. A., \& Berry, L. L. (1988). Servqual: A multiple-item scale for measuring consumer perc. Journal of retailing, 64(1), 12.

Park, J. W., Robertson, R., \& Wu C.L. (2004). The effect of airline service quality on passengers' behavioral intentions: a Korean case study. Journal of Air Transport Management, 10, 435-439.

Pittino, D., Martínez, A. B., Chirico, F., \& Galván, R. S. (2018). Psychological ownership, knowledge sharing and entrepreneurial orientation in family firms: The moderating role of governance heterogeneity. Journal of Business Research, 84, 312-326.

Pitchayadejanant, K., \& Nakpathom, P. (2016). The Effect of Demographic Information as Moderator toward Relationship between Service Quality, Customer Satisfaction, and Customer Loyalty in Thai Low Cost Carriers' Passengers. Journal of Marketing Management, 4(1), 172-182.

Platonova, E. A., Kennedy, K. N., \& Shewchuk, R. M. (2008). Understanding patient satisfaction, trust, and loyalty to primary care physicians. Medical Care Research and Review, 65(6), 696-712.

Qasim, S.S. (2015). Airline Service Quality in Pakistan - A Customer Preferences Approach, Pakistan Business Review, 99-112. 
Rahim Hussain, (2016),"The mediating role of customer satisfaction: evidence from the airline industry", Asia Pacific Journal of Marketing and Logistics, Vol. 28 Iss 2 pp. 234 - 255 Permanent link to this document: http://dx.doi.org/10.1108/APJML-01-

Ringle, C. M., Wende, S., \& Will, A. (2010). Finite mixture partial least squares analysis: Methodology and numerical examples. In Handbook of partial least squares (pp. 195-218). Springer, Berlin, Heidelberg.

Rizan, M. (2010), “Analysis of service quality and customers' satisfaction, and its influence on customers' loyalty", available at: www.studymode.com/essays/Analysis-OfService-Quality-And-Customer-937877.html (accessed October 10, 2013).

Román, S. (2003). The impact of ethical sales behaviour on customer satisfaction, trust and loyalty to the company: An empirical study in the financial services industry. Journal of Marketing Management, 19(9-10), 915-939.

Ruiz, D., Castro, B., \& Diaz, I. (2012). Creating customer value through service experiences: An empirical study in the hotel industry. Tourism and Hospitality Management, 18(1), 37-53.

Ryu, K., \& Han, H. (2010). Influence of the quality of food, service, and physical environment on customer satisfaction and behavioral intention in quick-casual restaurants: Moderating role of perceived price. Journal of Hospitality \& Tourism Research, 34(3), 310-329.

Ryu, k., Lee, H., \& Kim, W. (2012). The influence of the quality of the physical environment, food, and service on restaurant image, customer perceived value, customer satisfaction, and behavioral intentions. International Journal of Contemporary Hospitality Management, 24(2), 200-223.

Shirsavar, H. A., Gilaninia, S., \& Almani, A. M. (2012). A study of factors influencing positive word of mouth in the Iranian banking industry. Middle-East Journal of Scientific Research, 11(4), 454-460.

Slåtten, T., Krogh, C., \& Connolley, S. (2011). Make it memorable: customer experiences in winter amusement parks. International Journal of Culture, Tourism and Hospitality Research, 5(1), 80-91.

Spreng, R. A., \& Page, T. J. (2003). A test of alternative measures of disconfirmation. Decision Sciences, 34(1), 31-62.

Srivastava, M. (2015). Influencers of Customer Satisfaction, Customer Loyalty Relationship A Conceptual Research Model. Journal of Faculty of Management Studies, Banaras Hindu University, 7(1), 54-65.

Szymanski, D.M. and Henard, D.H. (2001), "Customer satisfaction: a meta-analysis of the empirical evidence", Journal of the Academy of Marketing Science, Vol. 29 No. 1, pp. 16-35

Taleghani, M., Biabani, S., Gilaninia, S., Rahbarinia, S. A., \& Mousavian, S. J. (2011). The relationship between customer satisfaction and relationship marketing benefits. Arabian Journal of Business and Management Review, 1(3), 78-86.

Teimouri, M., Yaghoubi, N. M., \& Kazemi, M. (2012). The Effect of Electronic Service Quality on Customers Behavioral Intentions. International Journal of Marketing Studies, 4(2), 179.

Terblanche, N. S., \& Boshoff, C. (2001). Measuring customer satisfaction with some of the controllable elements of the total retail experience: An exploratory study. South African Journal of Business Management, 32(2), 35-42.

Thomas, A. R. (2001). Air Rage. Crisis in the Skies. Prometheus Books.

Thomas, J. L., Cunningham, B. J., \& Williams, J. K. (2002). The impact of involvement, perceived moral intensity, and satisfaction upon trust in non-profit relational contexts: 
Pakistan Journal of Humanities and Social Sciences, 6(4), 2018

Processes and outcomes. Journal of Nonprofit \& Public Sector Marketing, 10(1), 93115.

Usta, M., Berezina, K., \& Cobanoglu, C. (2014). The impact of hotel attributes' satsifaction on overall guest satisfaction. Journal of Service Management, 6(3), 1-12.

Yang, J., \& Chen, Z. (2010). Cloud computing research and security issues. In Computational intelligence and software engineering (CiSE), international conference on (pp. 1-3). IEEE.

Yee, R. W., Yeung, A. C., \& Cheng, T. E. (2008). The impact of employee satisfaction on quality and profitability in high-contact service industries. Journal of operations management, 26(5), 651-668.

Yen, C. H., \& Lu, H. P. (2008). Effects of e-service quality on loyalty intention: an empirical study in online auction. Managing Service Quality: An International Journal, 18(2), 127-146.

Zaheer, M., Akbar, M. T., \& Ramzan, M. (2013). Image building in airline industry: A case of Pakistan International Airline. Interdisciplinary Journal of Contemporary Research in Business, 5(2), 192-204.

Zakir, F., Rehman, A., \& Rehman, Z. U. (2016). Effect of e-Supply Chain Management on the Business Process of Airline Industry. International Journal of Management Sciences and Business Research, 5(7).

Zhao, L., Lu, Y., Zhang, L., \& Chau, P. Y. (2012). Assessing the effects of service quality and justice on customer satisfaction and the continuance intention of mobile valueadded services: An empirical test of a multidimensional model. Decision support systems, 52(3), 645-656.

Zhu, Y. Q., \& Chen, H. G. (2012). Service fairness and customer satisfaction in internet banking: Exploring the mediating effects of trust and customer value. Internet Research, 22(4), 482-498. 